\title{
PENINGKATAN PENERIMAAN DIRI DAN GAMBARAN DIRI WANITA MENOPAUSE DENGAN ACCEPTANCE AND COMMITMENT THERAPY
}

\author{
CHINDY MARIA ORIZANI \\ AKADEMI KEPERAWATAN ADI HUSADA SURABAYA \\ chindyorizani@yahoo.com
}

\begin{abstract}
Menopausal phase could impact the physical, psychological, social, economic, spiritual and quality of life. Changes appear on the physical aspects could cause decreasing self-image in menopausal women, whereas the psychological changes that arise sometimes menopausal women experience a decrease in self-acceptance. The aim of this study is to prove the existence of increased acceptance and self-image menopausal women with Acceptance and Commitment Therapy. The design used is Quasy Experiment Pre-posttest with Controlled Group Design. The sample was menopausal women who are willing to become respondents as many as 40 people, divided into two groups: a control group of 20 people and 20 people treated group. Sampling technique using consecutive sampling. The independent variable for the provision of Acceptance and Commitment Therapy is divided into two sessions of four meetings (1x meeting two sessions). The dependent variable is self-acceptance and self-image menopausal women. Measuring instruments used in the form of a questionnaire. Analysis of data used computer software. The majority of respondents were married women, Muslim, Javanese, recent education junior high school and not working. The results proved statistically there was increasing acceptance between control and treatment groups $(p=0.000)$. Self-image measurement results proved no increase between control and treatment groups $(p=0.000)$. Acceptance and Commitment Therapy is highly effective for improving acceptance and self image in menopausal women. The active role of the respondents strongly supported upon the success of therapy and need the support of her husband and peers.
\end{abstract}

\begin{abstract}
ABSTRAK
Masa menopause dapat berdampak pada aspek fisik, psikologis, sosial, ekonomi, spiritual dan kualitas hidup seseorang. Perubahan yang muncul pada aspek fisik mengakibatkan penurunan gambaran diri wanita menopause, sedangkan perubahan psikologis yang muncul terkadang wanita menopause mengalami penurunan penerimaan diri. Tujuan dari penelitian ini adalah membuktikan adanya peningkatan penerimaan dan gambaran diri wanita menopause dengan Acceptance and Commitment Therapy. Desain yang digunakan adalah Quasy Experiment Pre-Posttest with Controlled Grup Design. Sampel penelitian ini adalah wanita menopause yang bersedia menjadi responden sebanyak 40 orang, dibagi menjadi dua grup, yaitu 20 orang grup kontrol dan 20 orang grup perlakuan. Teknik sampling menggunakan consecutive sampling. Variabel independen berupa pemberian Acceptance and Commitment Therapy empat sesi dibagi menjadi dua pertemuan (1x pertemuan dua sesi). Variabel dependen yaitu penerimaan diri dan gambaran diri wanita menopause. Alat ukur yang digunakan berupa kuesioner. Analisis data menggunakan software computer. Mayoritas responden adalah wanita menikah, beragama Islam, suku Jawa, pendidikan terakhir smp dan tidak bekerja. Hasil penelitian secara statistik terbukti ada peningkatan penerimaan diri antara grup kontrol dan perlakuan $(p=0,000)$. Hasil pengukuran gambaran diri terbukti ada peningkatan antara grup kontrol dan perlakuan $(p=0,000)$. Acceptance and Commitment Therapy ini sangat efektif untuk meningkatkan penerimaan dan gambaran diri pada wanita menopause. Peran aktif responden sangat mendukung kesusksesan terapi dan butuh dukungan dari suami dan teman sebaya.
\end{abstract}

Keywords: Menopausal Women's Self-Acceptance, Menopausal Women's Self-Image, Acceptance and Commitment Therapy 


\section{PENDAHULUAN}

Seorang wanita yang memasuki masa menopause akan mengalami berbagai macam gejala fisik antara lain ketidakstabilan vasomotor, gejala psikologis, gangguan urogenital dan mulai munculnya penyakit degeneratif. Masa perubahan saat menopause dapat menimbulkan kekhawatiran pada wanita, banyak keluhan muncul akibat kondisi fisik maupun respon negatif dari lingkungan. Wanita menopause akan sangat sensitif terhadap dampak fluktuasi hormonal. Keadaan ini dapat menghilangkan percaya diri, kebanggaan akan dirinya sebagai wanita dan akan mempengaruhi hubungan komunikasi dengan suami, anggota keluarga lain dan lingkungan sosial. Kecemasan yang dialami juga akan berpengaruh terhadap aktivitas harian, dimana sebelumnya wanita mampu melakukan pekerjaannya dengan baik dapat berubah menjadi kekacauan, hal ini timbul karena berkurangnya kemampuan fisik serta dampak psikologis yang timbul. ${ }^{3}$

Badan Pusat Statistik (2004), proyeksi penduduk 2014 menunjukkan jumlah wanita yang menghadapi masa menopause diperkirakan mencapai 15,2 juta orang. ${ }^{4}$ Menurut WHO tahun 2005, seluruh wanita di dunia mengalami keluhan pada masa menopause tercacat $17 \%$ mengalami gejala hebat, dan mengalami gejala ringan mencapai $34 \%$, sedangkan $49 \%$ tergolong sedang. Studi pendahuluan yang dilakukan oleh peneliti ditemukan pada tujuh Posyandu Lansia di Wilayah Puskesmas Mojo, Kelurahan Mojo, Kecamatan Gubeng, Kota Surabaya terdapat 320 wanita berusia 57-78 tahun dan pada kondisi pre, peri maupun pasca menopause. Hasil wawancara yang dilakukan secara sederhana pada 50 wanita menopause, 60\% diantaranya terkadang masih merasa cemas, memiliki persepsi negatif tentang masa menopause, dan perasaan kurang nyaman pada kondisi saat ini. $100 \%$ dari 50 wanita tersebut berstatus menikah dan tinggal bersama suami. 10 wanita diantaranya menyatakan merasa kulit bertambah keriput, takut melakukan hubungan seksual dengan suami terlalu sering dibandingkan sebelum menopause dan merasa ada bagian dirinya yang hilang. Sebagian besar wanita menyatakan belum pernah mendapatkan penyuluhan atau konseling tentang menopause sehingga berharap ada program khusus yang bertema menopause di kegiatan ibu PKK maupun posyandu lansia.

Terapi bagi wanita menopause seharusnya tidak hanya berfokus pada satu aspek saja namun harus secara holistik. Acceptance and Commitment Therapy (ACT) merupakan salah satu bentuk Cognitive Behavior Therapy (CBT) yang cukup efektif dalam mengurangi kecemasan, meningkatkan aspek psikologis yang lebih fleksibel atau kemampuan untuk menjalani perubahan yang dialami agar menjadi lebih baik. ACT dapat meningkatkan penerimaan diri dan gambaran diri pada wanita menopause.

Penelitian ini mencoba membuktikan pengaruh ACT sebagai salah satu upaya untuk meningkatkan penerimaan diri dan gambaran diri melalui perbaikan psikologis klien yang dapat memunculkan respon dan koping adaptif klien dalam mengatasi masalah perubahan saat menopause.

\section{METODE PENELITIAN}

Penelitian ini merupakan peneliian experimental dengan desain desain penelitian randomized control group pretest posttest design. Ada 2 kelompok yang terlibat dalam penelitian ini yaitu kelompok kontrol dan kelompok perlakuan. Kelompok perlakuan menerima perlakuan berupa Acceptance and Commitment Therapy (ACT), serta kelompok kontrol menerima penyuluhan dan pemberian leaflet.

Populasi penelitian ini adalah seluruh wanita menopause di Posyandu Lansia 
Wilayah Puskesmas Mojo, Kelurahan Mojo, Kecamatan Gubeng, Kota Surabaya. Pengambilan sampel menggunakan Consecutive Sampling dan mencakup kriteria inklusi dan eksklusi yang telah ditetapkan oleh peneliti. Kriteria inklusi yang ditentukan peneliti adalah: wanita peri-pasca menopause usia 46-65 tahu, memiliki suami, bersedia menjadi responden dan kooperatif. Kriteria eksklusi penelitian ini adalah: wanita menopause yang mendapatkan terapi pengganti hormon, memiliki riwayat penyakit komplikasi yang membutuhkan perawatan, memiliki riwayat penyakit keganasan, mengalami dimensia/pikun dan buta huruf. Sampel yang telah bersedia kemudian dibagi menjadi dua kelompok besar melalui pengundian berdasarkan nomor genap dan ganjil. Nomor genap masuk kelompok kontrol dan ganjil masuk kelompok perlakuan. Kelompok besar dibagi lagi menjadi empat kelompok kecil, masing-masing kelompok terdapat empat angggota, satu kader posyandu sebagai fasilitator dan terapis (peneliti).

Penelitian dilaksanakan selama enam minggu, pengambilan data pretest dilakukan pada minggu pertama, sesi I-IV dilakukan pada minggu ke-2 hingga ke ke-5 dan pengambilan data posttest pada minggu ke-6. Setiap sesi dilaksanakan 1-2x pertemuan/minggu dengan metode diskusi secara berkelompok dan konseling secara personal. Penelitian berjalan pada bulan Mei-Juni 2014. Lokasi penelitian adalah di balai RW II, RW VIII, RW X, RW XVI, Kelurahan Mojo, Kecamatan Gubeng, Kota Surabaya.

Variabel independen yang diteliti adalah pemberian Acceptance and Commitment Therapy empat sesi. Variabel dependen dari penelitian ini adalah harga diri dan persepsi kualitas hidup. Kuesioner yang digunakan peneliti adalah kuesioner Berger's SelfAcceptance Scale sebanyak 36 item pertanyaan dan The Multidimensional BodySelf Relations Questionnaire sebanyak 69 item pertanyaan yang telah diterjemahkan dalam Bahasa Indonesia. Kuesioner tersebut telah dilakukan uji validitas dan reliablitas dan hasilnya menunjukkan valid dan reliabel.

Hasil data yang diperoleh kemudian dilakukan tabulasi dan diolah menggunakan software statistik. Analisis yang digunakan yaitu Paired T Test dan Independent T Test. Paired $T$ Test digunakan untuk mengetahui perbedaan skor pre-post kelompok perlakuan maupun kelompok kontrol sedangkan Independent $T$ Test digunkan untuk mengetahui perbedaan antara skor posttes kelompok kontrol dan posttes kelompok perlakuan. Penelitian ini menggunakan tingkat signifikansi sebesar $p<0,005$.

\section{HASIL}

Total responden yang dilibatkan dalam penelitian ini adalah 20 orang kelompok perlakuan dan 20 orang kelompok kontrol. Responden yang terlibat dalam penelitian ini sebagian besar berusia 51-58 tahun. Karakteristik responden berdasarkan umur menunjukkan rentang masa menopause. Keluhan fisik maupun psikologis muncul pada masa menopause. Responden berdasarkan jenjang pendidikan terakhir sebagian besar berpendidikan SMP yaitu 27 orang $(67,5 \%)$, menunjukkan tingkat relatif rendah. Karakteristik responden berdasarkan penghasilan sebagian besar menunjukkan penghasilan cukup yaitu 32 orang (80\%). Berdasarkan pekerjaan sebagian besar adalah ibu rumah tangga yaitu 31 orang $(77,5 \%)$. Responden ibu rumah tangga rawan mengalami ketidakstabilan mood. Respon emosional dan asumsi yang sering muncul pada wanita tidak bekerja atau sering berdiam diri dirumah cenderung negatif, misalnya cemas memikirkan kondisi tubuh dan wajahnya yang keriput. Karakteristik responden berdasarkan rentang usia menopause saat dilakukan pendataan mayoritas adalah wanita yang mengalami menopause 1-3 tahun yaitu 30 orang (75\%). Wanita menopause dengan rentang 1-3 tahun 
adalah masa menopause dimana masih mengalami gejala perubahan menopause yang dianggap membawa masalah pada responden.

Hasil yang didapatkan dalam penelitian pengaruh ACT terhadap harga diri dan persepsi kualitas hidup dalam tabel berikut:

\section{Pengaruh ACT terhadap peningkatan Penerimaan diri}

Tabel 1. Tabulasi Silang Skor Penerimaan Diri pada Kelompok Kontrol dan Perlakuan Sesudah Intervensi

\begin{tabular}{|c|c|c|c|c|c|c|c|}
\hline & \multicolumn{2}{|c|}{ Naik } & \multicolumn{2}{|c|}{ Tetap } & \multicolumn{2}{|c|}{ Turun } & \multirow{2}{*}{$\begin{array}{l}\text { Total } \\
\mathrm{n}\end{array}$} \\
\hline & $\mathrm{n}$ & $\%$ & $\mathrm{n}$ & $\%$ & $\mathrm{n}$ & $\%$ & \\
\hline $\mathrm{K}$ & 10 & 50 & 3 & 15 & 7 & 35 & 20 \\
\hline $\mathrm{P}$ & 20 & 100 & 0 & 0 & 0 & 0 & 20 \\
\hline
\end{tabular}

Paired t test pre-post kelompok kontrol $\mathrm{p}=0.481$

Paired t test pre-post kelompok perlakuan $\mathrm{p}=0.000$

Independent t test post-post kelompok kontrol \& perlakuan $\mathrm{p}=0.000$

\footnotetext{
${ }^{*} \mathrm{n}=$ jumlah responden

$\mathrm{K}=$ kelompok Kontrol

$\mathrm{P}=$ kelompok Perlakuan
}

Berdasarkan tabel 1. menunjukkan bahwa mayoritas responden kelompok kontrol yang tidak mendapatkan pelatihan ACT mengalami kenaikan skor penerimaan diri yaitu 10 orang $(50 \%)$, sedangkan pada seluruh responden kelompok perlakuan yang mendapatkan pelatihan ACT mengalami kenaikan skor penerimaan diri (100\%). Hasil uji Paired T Test skor pretest dan posttest pada kelompok kontrol menunjukkan nilai $p=0,481 \quad(p<0,05)$, hal ini menunjukkan tidak terdapat perbedaan antara skor pretest dan posttest.

Hasil uji Paired T Test skor pretest dan posttest pada kelompok perlakuan menunjukkan nilai $p=0,000(p<0,05)$, hal ini menunjukkan terdapat perbedaan antara skor pretest dan posttest.
Pengujian efektifitas ACT pada skor harga diri antara kelompok kontrol dan perlakuan dengan menggunakan uji Independent $T$ test menunjukkan hasil $\mathrm{p}=0,000$ $(p<0,05)$, hal ini menunjukkan bahwa terdapat perbedaan antara kelompok kontrol dan kelompok perlakuan. Hasil kedua uji statistik menunjukkan adanya perbedaan sehingga dapat disimpulkan bahwa hipotesis penelitian diterima yaitu terdapat pengaruh ACT pada peningkatan penerimaan diri wanita menopause.

\section{Pengaruh ACT terhadap peningkatan gambaran diri}

Tabel 2. Tabulasi Silang Skor gambaran diri pada Kelompok Kontrol dan Perlakuan Sesudah Intervensi

\begin{tabular}{|c|c|c|c|c|c|c|c|}
\hline & \multicolumn{2}{|c|}{ Naik } & \multicolumn{2}{|c|}{ Tetap } & \multicolumn{2}{|c|}{ Turun } & \multirow{2}{*}{$\begin{array}{c}\text { Total } \\
n\end{array}$} \\
\hline & $\mathrm{n}$ & $\%$ & $\mathrm{n}$ & $\%$ & $\mathrm{n}$ & $\%$ & \\
\hline $\mathrm{K}$ & 9 & 56,25 & 4 & 18,75 & 7 & 25 & 16 \\
\hline $\mathrm{P}$ & 19 & 100 & 1 & 0 & 0 & 0 & 16 \\
\hline \multicolumn{8}{|c|}{ Paired t test pre-post kelompok kontrol $\mathrm{p}=0.629$} \\
\hline \multicolumn{8}{|c|}{ Paired t test pre-post kelompok perlakuan $\mathrm{p}=0.000$} \\
\hline & & $\mathrm{p}$ & & $1 \mathrm{p}=0 . \mathrm{c}$ & & 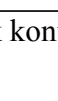 & \\
\hline
\end{tabular}

\footnotetext{
*n= jumlah responden

$\mathrm{K}=$ kelompok Kontrol

$\mathrm{P}=$ kelompok Perlakuan
}

Berdasarkan tabel 2. menunjukkan bahwa mayoritas responden kelompok kontrol yang tidak mendapatkan pelatihan ACT mengalami kenaikan skor gambaran diri yaitu 9 orang $(56,25 \%)$, sedangkan pada seluruh responden kelompok perlakuan yang mendapatkan pelatihan ACT mengalami kenaikan skor gambaran diri (100\%). Hasil uji Paired $T$ Test pada kelompok kontrol menunjukkan nilai $p=0,168(p<0,05)$, hal ini menunjukkan tidak terdapat perbedaan antara skor pretes dan posttes. Data pre dan postes menunjukkan rerata skor terendah dilihat pada domain seksual, sedangkan rerata 
skor tertinggi dapat dilihat pada domain okupasional. Hasil uji Paired $T$ Test pada kelompok perlakuan menunjukkan nilai $p=0,000 \quad(p<0,05)$, hal ini menunjukkan terdapat perbedaan antara skor pretes dan posttes.

Pengujian efektifitas ACT pada skor gambaran diri antara kelompok kontrol dan perlakuan dengan menggunakan uji

Independent $T$ test menunjukkan hasil $\mathrm{p}=0,004$ $(\mathrm{p}<0,05)$, hal ini menunjukkan bahwa terdapat perbedaan antara kelompok kontrol dan kelompok perlakuan. Hasil kedua uji statistik menunjukkan adanya perbedaan sehingga dapat disimpulkan bahwa hipotesis penelitian diterima yaitu terdapat pengaruh ACT pada peningkatan gambaran diri wanita menopause.

\section{PEMBAHASAN}

Pengaruh ACT Terhadap Peningkatan Penerimaan Diri pada Wanita Menopause.

Hasil penelitian menunjukkan bahwa hampir seluruh responden kelompok perlakuan mengalami peningkatan penerimaan diri menjadi baik. Penerimaan diri atas perubahan yang terjadi pada dirinya saat menopause dapat dipengaruhi oleh faktor: faktor fisik, kognitif, dan sosial lingkungan. ${ }^{2}$ Faktor fisik yang mempengaruhi adalah responden tidak mampu untuk menerima kondisi perubahan tubuhnya. Sedangkan secara kognitif, perubahan tersebut membawa dampak negatif pada pikiran wanita menopause sehingga tidak mampu menerima kondisi yang dialaminya. Faktor sosial dan lingkungan membawa dampak negatif pula ketika lingkungan menjadi faktor penghambat peningkatan penerimaan diri pada seorang wanita menopause. Kecemasan akan ketidakmampuan penyelesaian tugas rumah tangga, kekhawatiran dan ketidakpuasan pasangan muncul sebagai penghambat penerimaan diri.

Setelah pemberian ACT, mayoritas seluruh responden mengalami peningkatan harga diri (100\%). Pernyataan didukung dari hasil statistik data posttest kelompok perlakuan yang terbukti ACT berpengaruh terhadap peningkatan penerimaan diri.
Penerimaan diri menurut Chaplin (2004) adalah sikap yang merupakan rasa puas pada kualitas dan bakat, serta pengakuan atas keterbatasan. Hal tersebut terjadi karena dalam sesi ACT responden diminta untuk mengidentifikasi masalah dan keterbatasan yang dialaminya. Menurut Hayes (2007), terapi ACT adalah suatu terapi yang bertujuan untuk meningkatkan aspek psikologi yang lebih fleksibel atau kemampuan untuk menjalani perubahan yang terjadi saat ini dengan lebih baik. Hal ini dapat diperoleh setelah seseorang melaksanakan sesi 1-3 dalam ACT. Pada sesi 1: identifikasi kejadian, pikiran, dan perasaan yang muncul dan menghilangkan pikiran negatif (acceptance \& cognitive defusion). Penerimaan (acceptance) bermakna menerima, sehingga penekanannya adalah bahwa seseorang harus terlebih dulu mengerti mengenai keadaannya, setelah itu barulah ia mampu menerima kondisinya dengan menghilangkan pikiran-pikiran negatif (cognitife defusion).

Seseorang akan menerima kondisinya apabila mendapat pengetahuan cukup mengenai kondisi yang dialaminya yang akan mengubah persepsinya menjadi positif sehingga koping juga positif. Sesi kedua dan ketiga ini bermanfaat untuk meningkatkan kepercayaan diri klien bahwa mereka mempunyai kemampuan untuk menerima kejadian dan menentukan nilai-nilai positif terkait penatalaksanaan menopause melalui identifikasi pengalaman yang positif. Hal ini membuat seseorang optimis dalam merencanakan kegiatan positif untuk mengatasi harga diri rendah yang dialami sehingga mempunyai perasaan lebih dapat menerima. Pada sesi keempat, responden dapat menyusun kegiatan yang positif dan berkomitmen untuk menjalankan kegiatan tersebut sehingga dapat meningkatkan harga dirinya.

\section{Pengaruh ACT Terhadap Peningkatan Gambaran Diri pada Wanita Menopause.}

Hasil penelitian menunjukkan bahwa
hampir seluruh responden kelompok
perlakuan mengalami peningkatan gambaran
diri menjadi baik. Gambaran diri pada wanita


menopause cenderung menurun disebabkan karena perubahan fisik yang dialami mengakibatkan perubahan persepsi wanita menopause tentang gambaran dirinya. Setelah dilakukan program ACT, gambaran diri menjadi lebih baik dikarenakan wanita diajak menyadari walaupun terjadi perubahan fisik, wanita menopause diajak untuk tetap mempertahankan kesehatan fisik. Olahraga ringan dapat mengurangi keluhan yang selalu muncul saat menopause. ACT membantu wanita menopause sebagai sebuah intervensi keperawatan yang sejalan dengan prinsip Nursing Therapeutic sehingga respon negatif misalnya rendahnya penerimaan diri dan ketidakmampuan seseorang menimbulkan koping positif akan masalah yang dihadapinya dapat memperbaiki respon tersebut menjadi positif dan mampu berkomitmen untuk menjalani tugas sesuai kemampuan yang dimiliki.

Hasil pengamatan selama penelitian, perubahan sikap terlihat pada tiap responden yaitu cara berkomunikasi yang baik, kemampuan dalam menjalankan tugas, melakukan sharing pendapat secara efektif dan adanya touch satu sama lain mampu menguatkan dan meningkatkan harga diri. Sedangkan secara kognitif, perubahan yang terjadi yaitu dari pikiran negatif menjadi pikiran positif, respon emosi yang stabil, pemecahan masalah yang positif (dilakukan doa, kontemplasi dan olahraga), dukungan sosial yang baik antar individu dalam kelompok, penerimaan yang baik dan komitmen dalam menjalankan tugas dengan baik.

\section{SIMPULAN}

Intervensi berupa Acceptance and Commitment Therapy pada wanita menopause dapat meningkatkan penerimaan dan gambaran diri pada wanita menopause. ACT membantu wanita menerima kondisi yang dialami dan menyelesaikan masalah sesuai kemampuannya, mampu beradaptasi dan hidup lebih baik.

\section{SARAN}

Peneliti menyarankan pada penelitian selanjutnya dilakukan dengan desain kuantitatif dan melibatkan keluarga terutama suami dalam program ACT. Petugas baik dari Puskesmas maupun kader Posyandu lansia dapat menggunakan ACT sebagai salah satu intervensi mandiri untuk meningkatkan kualitas hidup wanita menopause.

\section{DAFTAR PUSTAKA}

1. Bazaid Ali. 2003. Endokrinologi Ginekologi. Jakarta: Media Aesculapius

2. Chaplin, J.P. 2004. Kamus Lengkap Psikologi. Jakarta : Raja Grafindo Persada.

3. Judd, FK., Hickey, M., Bryant, C. 2012. Depression and Midlife: Are we Overpathologising the Menopause. Journal of Affective Disorders. 136: 199211

4. Larasati, A. 2007. Pembelajaran Kontekstual. Yogyakarta: Media Aksara

5. Larasati, T. 2006. Jurnal Kulitas Hidup pada Wanita yang Sudah Memasuki Msa Menopause. Gunadarma: unpublished.

6. Manuaba. 2009. Buku Ajar Patologi Obstetri. Jakarta: EGC

7. Manuaba. 2009. Ilmu Kebidanan, Penyakit Kandungan dan Keluarga Berencana untuk Pendidikan Bidan. Jakarta: EGC

8. Martaadisoebrata. 2005. Bunga Rampai Obsteri Ginekologi Sosial. Jakarta: Yayasan Bina Pustaka Sarwono Prawiroharjo

9. Varney, H. 2004. Buku Ajar Asuhan Kebidanan. Jakarta: EGC 